\title{
PERAN EMPLOYEE AGILITY DALAM PERUSAHAAN
}

Angelita Nauli Panggabean - 2301950881 - LB21

E-Business Strategy and Implementation

\begin{abstract}
Abstrak
Saat ini, hampir semua perusahaan menghadapi lingkungan yang kompetitif, cepat berubah, dan kompleks. Hal ini menyebabkan perusahaan untuk dapat lebih reponstif dan beradaptasi dengan cepat demi menghasilkan keuntungan di pasar. Strategi yang sering dilakukan oleh perusahaan adalah dengan memiliki karyawan yang lincah atau gesit. Dengan demikian, tujuan dari tinjauan pustaka ini adalah untuk melihat peran Employee Agility dalam perusahaan yang menghadapi perubahan baru. Metode yang digunakan adalah dengan mengumpulkan serta mempelajari jurnaljurnal. Jurnal tersebut didapatkan dari berbagai sumber melalui internet.
\end{abstract}

Kata Kunci: Agility, Employee Agility, Kelincahan Karyawan

\section{Pendahuluan}

Perkembangan dan persaingan global yang pesat dan terus berubah saat ini, telah menyebabkan kompleksitas dan perubahan yang cepat di lingkungan kerja. Proses menyikapi dan menanggapi perubahan besar yang terjadi ini adalah bergantung pada kemampuan dan kelincahan karyawan itu sendiri. Kemampuan karyawan dalam beradaptasi merupakan salah satu kunci keberhasilan perusahaan. Oleh sebab itu, Agility atau kelincahan merupakan hal yang penting dan telah menjadi kebutuhan bagi perusahaan demi mampu menghadapi situasi atau perubahan baru yang cepat. Kelincahan karyawan mengacu pada sejauh mana karyawan dapat segera merespon perubahan kecil maupun besar di lingkungan kerja. Dengan demikian, mulai banyak perusahaan yang mempertimbangkan untuk melakukan investasi pada karyawan, serta meningkatkan kelincahan mereka. Dalam penelitian (Hida Syahchari et al., n.d.), bahwa kelincahan karyawan dapat menjadi jawaban yang tepat untuk mencapai efektivitas perusahaan, dimana mereka mampu untuk mencoba mengintegrasikan pola pikir serta perilaku yang cepat ke dalam aktivitas bisnis sehari-hari. Faktanya, kelincahan karyawan menjadi sebuah urgensi dan kebutuhan perusahaan yang terus meningkat. Oleh karena itu, telah membuat penulis tertarik untuk memahami dan melihat seberapa penting peran kelincahan karyawan pada perusahaan berdasarkan jurnal-jurnal yang telah dipelajari.

\section{Literature Review}

\section{Agility}

Agility atau dalam Bahasa Indonesia adalah kelincahan, didefinisikan sebagai kemampuan sebuah perusahaan untuk beradaptasi dengan lingkungan yang terus berubah dengan cepat. 
Kemampuan untuk beradaptasi di tengah pasar yang kompleks dan bergejolak saat ini, akan menghasilkan keunggulan kompetitif jika perusahan berhasil merespons perubahan dengan cara yang tepat. Penerapan pola pikir yang lebih agile dalam perusahaan inilah akan berperan besar dalam kesuksesan perusahaan tersebut. Oleh karena itu, perusahaan berharap untuk mendorong kecepatan serta kemampuan beradaptasi dengan menerapakn strategi agility pada para pemimpin dan karyawan mereka. Berdasarkan (Petermann \& Zacher, 2020), menilai bahwa kelincahan bagi perusahaan adalah hal yang sangat penting, dan kelincahan ini akan semakin penting dalam tiga tahun ke depan. Dalam linkungan perusahaan yang agile atau gesit, karyawan akan cenderung berkomunikasi satu sama lain dengan baik demi keberhasilan perusahaan. Untuk itu, perusahaan dengan budaya yang gesit tidak akan khawatir dan takut akan kegagalan. Bahkan, sekali pun mengalami kegagalan, kegagalan itu akan diterima demi perbaikan yang lebih lagi. Menjadi agile memungkin perusahaan bergerak lebih cepat dan dapat mengungguli pesaing mereka. Faktanya, banyak perusahaan, seperti Spotify dan Zappos telah mendesain ulang perusahaan mereka agar lebih agile (Petermann \& Zacher, 2020). (Baran \& Bible, 2019) juga menyarakan, bahwa kelincahan sangat penting bagi organisasi untuk menangani perubahan yang dihadapi.

\section{Employee Agility}

Employee Agility didefinisikan sebagai kemampuan karyawan untuk merespons secara efektif dan tepat waktu terhadap perubahan yang dinamis dan terus berubah, serta mereka memanfaatkan perubahan tersebut untuk mencapai keuntungan maksimal. Employee Agility atau kelincahan karyawan dianggap sangat krusial untuk dimiliki karyawan dalam perusahaan. Hal ini karena, Employee Agility diharapkan akan meningkatkan kemampuan kecepatan dalam beradaptasi, inovasi, fleksibilitas, serta kemampuan karyawan terhadap perubahan-perubahan baru. Kelincahan karyawan ini dapat dilihat berdasarkan perspektif perilaku karyawan itu sendiri. Karyawan yang lincah biasanya memiliki perilaku yang proaktif, adaptif, dan generatif (Saad Mian \& Saad Mian, 2017). Pandangan ini dilihat pada bagaimana kemampuan karyawan dalam beradaptasi, serta bagaimana kemampuanya untuk secara proaktif merespons dan mempersiapkan perubahan demi menjadi lebih agile. Berdasarkan (Hida Syahchari et al., n.d.), bahwa perusahaan yang memiliki karyawan yang agile akan beradaptasi dengan cepat terhadap perubahan dan lonjakkan pasar, serta dapat merespons dengan tepat dan fleksible terhadap permintaan pelanggan. Dari definisi-definisi tersebut, ruang lingkup Employee Agility ini berfokus pada kemampuan karyawan dalam menangani ketidakpastian dan peluang baru (Bala et al., 2019). Menurut (Bala et al., 2019), seorang yang memiliki keterbukaan dan ekstraversi (seseorang yang minatnya lebih mengarah ke alam luar dari pada pengalaman sendiri) tinggi belum tentu lincah atau gesit di tempat kerja. Justru, menjadi agile atau lincah di tempat kerja adalah seseorang yang dapat memperhatikan, belajar, dan juga dapat menanggapi perubahan lingkungan pada situasi kerja. Berdasarkan penelitian (Rawashdeh \& Tibor, 2020) di sektor perbankan pun mengatakan, bahwa karyawan dengan kemampuan agile yang tinggi, mereka akan mampu menerapkan dan menghasilkan ouput inovatif yang lebih besar. Namun, perlu diperhatikan bahwa terdapat sebagian 
besar karayawan yang tidak mampu berperilaku inovatif dalam situasi stress atau dengan jadwal yang menuntut. Oleh karena itu, Employee Agility yang dianggap krusial ini, perusahaan harus berusaha untuk membuat lingkungan kerja yang lebih fleksibel dan sehat demi lingkungan kerja yang sehat, sehingga dapat membantu karyawan menjadi lebih agile bahkan dalam sitausi paling kritis sekalipun.

\section{Metode}

Karya tulis ini dibuat dengan metode literature review atau tinjauan pustaka, dimana penulis mengumpulkan dan mempelajari jurnal-jurnal untuk mencapai kesimpulan. Jurnal tersebut didapatkan dari berbagai sumber melalui internet.

\section{Kesimpulan}

Agility merupakan sesuatu yang tidak asing lagi, ketika menyakut tentang bagaimana perusahaan dapat secara efektif beradaptasi dengan perubahan yang bergejolak. Sedangkan, Employee Agility diartikan sebagai kemampuan karyawan dalam merespons perubahan yang terjadi dengan cepat dan efisien, serta dapat memanfaatkan perubahan yang ada sebagai peluang yang menguntungkan. Oleh karena itu, Employee Agility memiliki peran yang sangat penting dan krusial bagi perusahaan dalam menangani dan beradaptasi terhadap perubahan yang mereka hadapi.

\section{Reference:}

Bala, H., Massey, A. P., \& Seol, S. (2019). Social Media in the Workplace: Influence on Employee Agility and Innovative Behavior. https://hdl.handle.net/10125/59675

Hida Syahchari, D., Saroso, H., Sudrajat, D., Grace Herlina, M., \& W Jordaan, H. K. (n.d.). The Influence Of Digital Employee Experience And Employee Agility: Do They Boost Firm's Effectiveness?

Petermann, M. K. H., \& Zacher, H. (2020). Agility in The Workplace 1 Agility in the Workplace: Conceptual Analysis, Contributing Factors, and Practical Examples.

Saad Mian, S., \& Saad Mian, M. (2017). Impact of High Performance Work Practices (HPWPs) on the Employee Agility. https://doi.org/10.17758/ERPUB.DIRH1217205

Baran, B. E., \& Bible, S. C. (2019). Agility and Agile : An Introduction for People, Teams, and Organizations.

Rawashdeh, L., \& Tibor, D. (2020). Innovation and The Role of Employee Agility - A Case Study in Jordanian Banks. 